\title{
INHIBITION EFFECTS OF SILVER NANOPARTICLES AGAINST RICE BLAST DISEASE CAUSED BY MAGNAPORTHE GRISEA
}

\author{
ELAMAWI, RABAB M. A. ${ }^{1 *}$ and R. A. S. EL-SHAFEY ${ }^{2}$ \\ ${ }^{1}$ Rice Pathology Department, Plant Pathology Research Institute, BP 33717, ARC, \\ Sakha, Egypt. \\ 2 Rice Research and Training Center, Sakha, Kafr El-Sheikh, Field Crops Research \\ Institute, ARC, Sakha, Egypt \\ * Corresponding author: rabab.elamawi@yahoo.com
}

(Manuscript received 8 December 2013)

\begin{abstract}
Rice blast disease, caused by Magnaporthe grisea, is the most serious biotic threat to rice (Oryza sativa L.) production worldwide. It causes severe yield losses in Egypt especially in epidemic years. The fungus is highly variable so disease control is a challenge. In this study, the effect of silver nanoparticles $(20-30 \mathrm{~nm})$ against rice leaf blast fungus was evaluated under different cultivation conditions both in vitro and in vivo. Under lab conditions, the application of four concentrations of silver nanoparticles to the culture of M. grisea showed significant inhibition of both hyphal growth and number of colonies formed in a dose-dependent manner. Number of spores/ $\mathrm{ml}$ decreased with in all treatment. Under greenhouse conditions, Silver nanoparticles were sprayed in concentrations $0,25,50,100$ and $200 \mathrm{ppm}$ on rice seedling leaves at three times ( 3 hours before inoculation, 1 and 5 days after artificial inoculation with spore suspension). Damaged Leaf Area Percentage (DLA \%) indicated that the application of $100 \mathrm{ppm}$ silver nanoparticles was highly efficient before and after inoculation (26.7, 15.3 and $20 \%$ ), respectively compared to the untreated plants of $80 \%$. The chemical fungicides isoprothiolane (Fuji one) and azoxystrobin (Amistar) at a concentration of $100 \mathrm{ppm}$ each showed the lowest DLA (19.6\% and $14.7 \%$, respectively). Scanning electron microscope results revealed that the silver nanoparticles caused a detrimental effect on mycelial growth.

Keywords: Silver Nanoparticles, Rice, Magnaporthe grisea, fungicide.
\end{abstract}

\section{INTRODUCTION}

Rice (Oryza sativa L.) is a major staple food crop for half of the world's population. In Egypt, rice is the second staple food after wheat, and is important for local consumption and export. In Egypt, rice is annually grown in more than one million feddans, mostly in the Northern part of the Nile Delta. The cultivated area in 2010 season was 1.77 million feddans that produced about 6 million tons of paddy rice. This created an average yield of about 10.06 tons/ hectare, which is considered one of the highest average yield in the world (RRTC, 2010). However, rice diseases 
(especially rice blast) can reduce yield production by about $5 \%$ in normal or mild disease outbreaks, but during epidemics seasons the yield losses may reach as high as $30-50 \%$ (Sehly et al., 2002).

Rice blast, caused by the fungus Pyricularia grisea (Cooke) Sacc. [anamorph of Magnaporthe grisea (Hebert) Barr], is a devastating diseases of rice (Oryza sativa L.) worldwide (Ou, 1985). Around $50 \%$ of the production may be lost in a field moderately affected by infection (Zeigler et al., 1994). The disease is currently managed using resistant cultivars, fungicides and cultural practices. Most of the rice cultivars are susceptible to different fungus races. The pathogen is also highly variable so, breeding for durable resistance to blast remains a major challenge (Roy-Barman and Chattoo, 2005). Fungicides are commonly used to control blast; however, these are becoming less acceptable as they increase the potential for build-up of resistance in M. grisea to fungicides and also conflict with the public concern for fungicide residues on human health and environment (Coca et al., 2006).

Silver ions are very reactive, they inhibit microbial respiration and metabolism and they cause physical damage (Bragg and Rannie1974; Thurman et al., 1989). Silver has been used to treat medical ailments for over 100 years due to its natural antibacterial and antifungal properties (Morones et al., 2005). Recently, nanotechnology practices have amplified the effectiveness of silver particles as antimicrobial agents (Elchiguerra et al., 2005; Yeo et al., 2003). Silver nanoparticles have extremely large relative surface areas which increases their contact with bacteria and fungi, vastly improving its bactericidal and fungicidal effectiveness. The larger surface area-to-volume ratio of silver nanoparticles increases their contact with microbes and their ability to permeate cells. When in contact with bacteria and fungus, they will adversely affect cellular metabolism and inhibit cell growth. Silver suppresses respiration, basal metabolism of electron transfer systems, and transport of substrates in the microbial cell membrane. Nanoparticle development has restored interest in the antimicrobial effects of metals, which declined following the widespread application of modern synthetic antibiotics (Richards, 1981).

The use of nano-sized silver particles as antimicrobial agents has become more common as technological advances made their production more economical. There have been relatively few studies on the applicability of silver to control plant diseases; especially for sclerotia-forming species of Rhizoctonia solani, Sclerotinia sclerotiorum and S. minor (Min et al., 2009) and powdery mildew in cucurbits (Lamsal et al., 2011). Antifungal activity of ionic or nanoparticle silver has a great potential for use in controlling spore-producing fungal plant pathogens. Various forms of silver ions and 
nanoparticles were tested to examine the antifungal activity on two plant-pathogenic fungi, Bipolaris sorokiniana and Magnaporthe grisea (Young et al., 2009).

The objectives of this study were to determine the inhibitory property of silver nanoparticles on fungal growth and colony formation of Magnaporthe grisea, and to evaluate their efficacy for rice blast disease control.

\section{MATERIALS AND METHODS}

Silver nanoparticles and fungicide: Silver nanoparticles were obtained from King Abd Alla Institute for nanotechnology, College of Science, King Saud University, Saudi Arabia. According to the source, the particles size ranged from 20 to $30 \mathrm{~nm}$ and were spherical shape. Size and morphology of silver nanoparticles particles were confirmed by UV spectral analysis and Transmission Electron Microscopy (TEM). Different concentrations of silver nanoparticles $\left(25,50,100\right.$, and $\left.200 \mathrm{ug} \mathrm{m}^{-1}\right)$ were prepared by diluting the original stock solution using sterile deionized water. All solutions were stored at $4^{\circ} \mathrm{C}$ until use. The chemical fungicides isoprothiolane (Fuji one $40 \% \mathrm{EC}$ ) and azoxystrobin (Amistar 25\% SC) were used as controls.

Fungus preparation: Rice blast fungus was isolated from infected leaves of Sakha 101 rice cultivar during 2009 season from Gharbia governorate and identified as $M$. grisea race IG-1 according to disease reaction pattern on the international differential varieties (Atkins et al., 1967).

Inhibition of both hyphal growth and colony formation by silver nanoparticles: The antifungal activity of nanoparticles was examined based on hyphal growth and new colony formation in vitro. For measurement of hyphal growth: agar plugs ( $6 \mathrm{~mm}$ in diameter) were obtained from the actively-growing edge of a pure culture of M. grisea, inoculated in the center of Banana dextrose agar (BDA) medium (g/L: 200 Banana,15 glucose and 20 agar) supplemented with different concentrations of silver nanoparticles with four replicates. The inoculated plates were incubated at $28^{\circ} \mathrm{C}$ for 10 days. Colony diameter was measured every $48 \mathrm{hr}$ till the control reached its maximum. For new colony formation, conidia were collected from M. grisea cultures, grown on BDA medium, and incubated at $25^{\circ} \mathrm{C}$ for 10 days. Conidial suspension was diluted with sterile deionized water to a concentration of $10^{6}$ spores $-1 \mathrm{ml} .500 \mu \mathrm{l}$ of the conidial suspension were mixed with serial concentrations of silver particles to a final volume of $1 \mathrm{ml}$. Conidial suspension was also prepared with sterile deionized water as control or mixed with the fungicides in concern, Fuji-One and Amistar, at a concentration of $100 \mathrm{ug} \mathrm{ml}^{-1}$ each. All treatments were incubated at $28^{\circ} \mathrm{C}$ for $24 \mathrm{~h}$. aliquots of $25 \mu \mathrm{l}$ of each dilution was 
spread on BDA and incubated at $28^{\circ} \mathrm{C}$. The number of colonies formed on plates was counted after 2, 4 and 10 days. This experiment was repeated twice.

Scanning electron microscopy (SEM): Petri dishes containing M. grisea 10 days old cultures were sprayed with $1 \mathrm{ml}$ of $100 \mathrm{ug} \mathrm{ml}^{-1}$ silver nanoparticle solution, and observed under an electron microscope after 24 hours. The specimen was observed on a Hitachi S-3500N scanning electron microscope at an accelerating voltage of 10 kV at the faculty of Science, Tanta University.

Greenhouse assay: The efficacy of silver nanoparticals, against rice blast disease under greenhouse condition, was determined at the Rice Research and Training Center at Sakha station. One hundred seeds of Sakah 101 cultivar were seeded in pots. Four pots for each treatment were randomly arranged. Four concentrations of Silver nanoparticles solution $\left(0,25,50,100\right.$ and $\left.200 \mathrm{ug} \mathrm{ml}^{-1}\right)$ were applied at different times: 3 hrs before conidia inoculation (hbi), one and five days past inoculation (dpi). For pre-inoculation treatments, silver preparations were sprayed on 21-days old rice seedlings and allowed to air-dry at $25^{\circ} \mathrm{C}$ for $3 \mathrm{hrs}$ followed by inoculation with conidial suspensions $\left(10^{5}\right.$ conidia $\mathrm{ml}^{-1}+0.2 \%$ Tween 20$)$. Control and fungicides treatments, Fuji-One and Amistar at concentration $0.2 \mathrm{~cm}^{3} / 100 \mathrm{ml}$ and $0.12 \mathrm{~cm}^{3} / 100 \mathrm{ml}$, respectively were applied on rice plants after 5 days of inoculation. The inoculated plants were kept under plastic container. Spore suspension was sprayed using electrical spray gun. The inoculated seedlings were held in a moist chamber with at least $90 \%$ R.H. and $25-28{ }^{\circ} \mathrm{C}$ for $24 \mathrm{hr}$. and then moved to the greenhouse. Seven days after inoculation, the reaction was scored using the (0-9) scale of IRRI (1996).

Disease assessment: Leaf blast infection was assessed as a percentage by counting the number of infected leaves of 10 randomly selected leaves per pot at 10 days after inoculation. The total number of type 4 lesions on the infected leaves was used as criterion for severity of infection. The inoculation experiment was performed twice.

Damaged leaf area: The damaged leaf area for each treatment was calculated using the following formula:

$$
\text { Damaged leaf area (DLA) } \%=\frac{\text { Lesion no. } \times \text { lesion size }}{\text { Leaf area }} \times 100
$$

Statistical analysis: Data were subjected to analysis of variance (Gomez and Gomez, 1984), and means were compared according to Duncan's Multiple Range Test (Duncan, 1955). 


\section{RESULTS}

Characterization of silver nanoparticles: The silver nanoparticles were characterized by UV -Visible Spectrum, The absorption spectra of silver nanoparticles showed single-band absorption with peak maximum (Surface Plasmon Resonance, SPR) at the wavelength, $415 \mathrm{~nm}$ (Figure 1). According to the manufacturer and the TEM images, the particle sizes were ranged from 20 to $30 \mathrm{~nm}$ and were spherical in shape (Figure 2). The absorptions spectra are due to Plasmon excitations of particles (Bae et al., 2002). Distribution and particle sizes were mainly depending upon spectral analysis (Khanna et al., 2007).

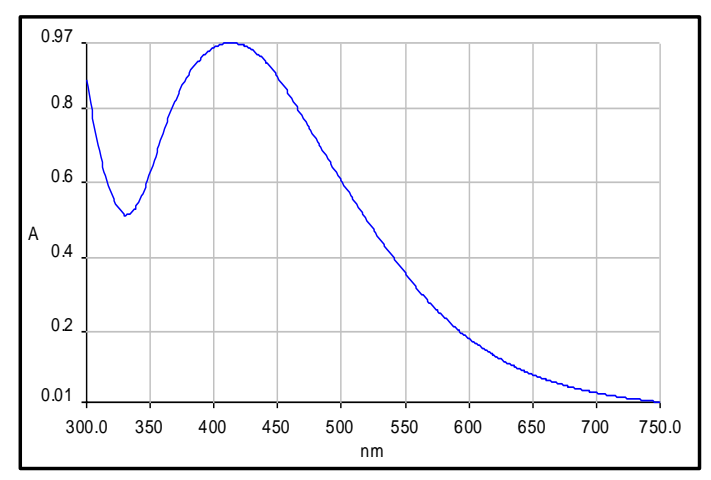

Figure 1. UV-Visible absorption spectrum of silver nanoparticles.

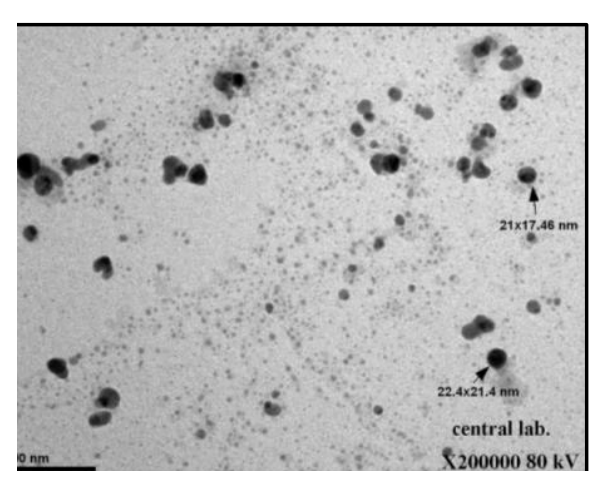

Figure 2. TEM picture of silver nanoparticles

\section{Effect of silver nanoparticles on hyphal growth and colony formation of $\boldsymbol{M}$.}

grisea: A remarkable inhibition of hyphal growth and abnormal patches of aerial hyphal mass were observed by the treatment of silver nanoparticles at all concentrations (Figure $3 \mathrm{~A}$ and 4). Measurement of radial growth revealed that the silver nanoparticle retarded and significantly reduced the fungal growth low at concentrations (Figure 3A). Fingers of hyphal growth developed on silver nanoparticles-supplemented medium compared to the control are showed in Table (1). The numbers of spores were counted 10 days after incubation on silver nanoparticles-supplemented medium. The number of spores/ $\mathrm{ml}$ was significantly decreased with all applications compared to the untreated control (Table 1).

Effects of silver nanoparticles on the new colony formation were assayed. Freshly obtained spore suspensions of $M$. grisea were incubated at different concentrations of silver nanoparticles or equal amount of water for $24 \mathrm{~h}$ at $28{ }^{\circ} \mathrm{C} .25 \mu \mathrm{l}$ of spore suspension were spread at BDA (Figure $3 \mathrm{~A}$ ). The colonies formations were counted 
after 2, 4 and 7 days whereas the silver nanoparticles treatments were retarded up to 7 days compared to those developed with the zero concentration, that appeared after 2 days and increased with time. Different antimicrobial efficiency of silver nanoparticles was observed on M. grisea colonies numbers. The growth inhibition with silver nanoparticles was dose-dependent (Figure 3B and Table 1).

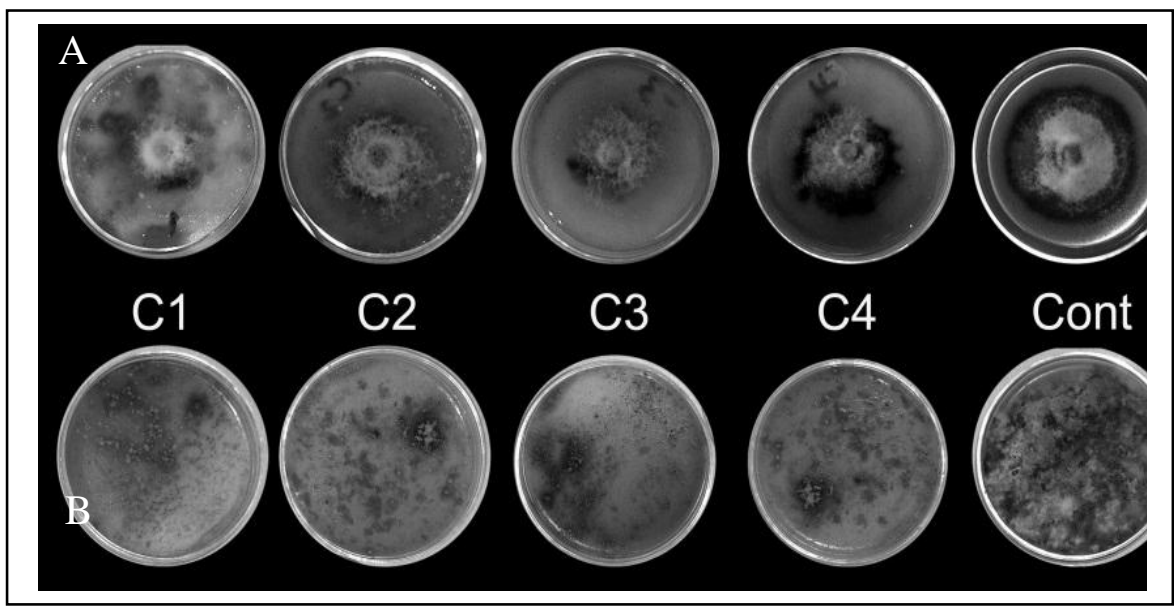

Figure 3. Effect of silver particles on hyphal growth and Number of colony formation of $M$. grisea after 10 days. A, Radial hyphal growth on BDA medium containing concentrations of silver nanoparticle after 10 days; $\mathrm{C} 1=25, \mathrm{C} 2=50, \mathrm{C} 3=100, \mathrm{C} 4=200$, Cont $=0 \mathrm{ug} \mathrm{ml}^{-1} . \mathrm{B}$, Number of colony formation on BDA medium. Suspension of fungal spores soaked for $24 \mathrm{~h}$ at different concentration of silver nanoparticles. $25 \mathrm{ul}$ of treated spores spread on BDA medium.

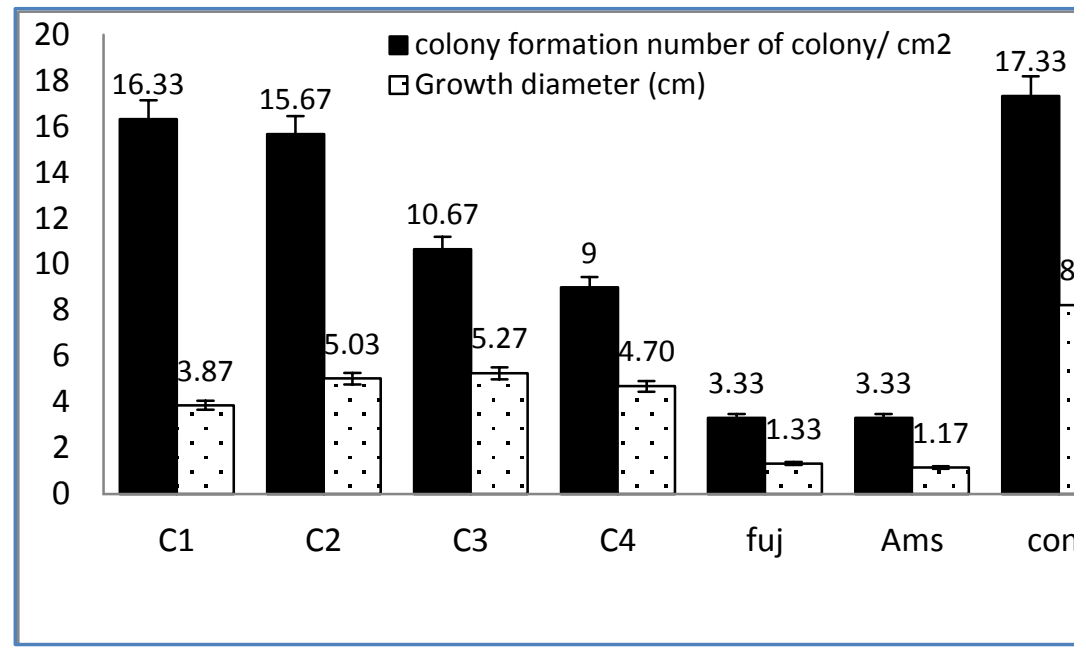

Figure 4: Relative hyphal growth rate and colony formation number on BDA medium containing silver nanoparticles concentrations; $\mathrm{C} 1=25, \mathrm{C} 2=50, \mathrm{C} 3=100$, $\mathrm{C} 4=200, \mathrm{Cont}=0 \mathrm{ppm}, \mathrm{fuj}=$ Fuji-one $(100 \mathrm{ppm})$ and Ams $=$ Amistar $(100 \mathrm{ppm})$. 
Table 1. Effect of silver nanoparticles on hyphal growth and colony formation compared to fungicides.

\begin{tabular}{|c|c|c|c|}
\hline $\begin{array}{l}\text { Concentration } \\
\left(\text { ug ml }{ }^{-1}\right)\end{array}$ & $\begin{array}{c}\text { Growth } \\
\text { diameter }(\mathrm{cm})\end{array}$ & $\begin{array}{c}* \text { No. of } \\
\text { spores /ml }\end{array}$ & $\begin{array}{c}\text { Number of formed- } \\
\text { Colonies }\left(\mathrm{cm}^{2}\right) \\
\end{array}$ \\
\hline Control (water) & 8.23 & 91.67 & 17.33 \\
\hline 25 & 3.87 & 13.19 & 16.33 \\
\hline 50 & 5.03 & 40.97 & 15.67 \\
\hline 100 & 5.27 & 10.42 & 10.67 \\
\hline 200 & 4.70 & 15.97 & 9 \\
\hline Fuji-one (100) & 1.33 & 4.167 & 3.33 \\
\hline Amistar (100) & 1.17 & 4.861 & 3.33 \\
\hline LSD 5\% & 0.473 & 25.7 & 3.984 \\
\hline$F$ & $* *$ & $* *$ & $* *$ \\
\hline
\end{tabular}

\section{Effect of silver nanoparticles on blast disease parameters under greenhouse}

conditions: the antifungal activity of the silver nanoparticles against $M$. grisea causing the rice blast disease at different concentrations was presented in Table (2) and illustrated in figure (5). Under greenhouse conditions, silver nanoparticles were applied 3 hours before spore inoculation, one and five days post spore inoculation. Silver nanoparticles effectively reduced blast lesion on Sakha 101 rice cultivar without noticeable phytotoxicity. All treated plants showed lower disease reaction either before or after inoculation compared to the untreated control. The average damasod leaf area DLA\% observed in the control plants was $80.0 \%$. Generally, the diseases differed significantly at $3 \mathrm{~h}$ before inoculation and one day after inoculation. The DLA $\%$ was significantly lower in rice plants treated with silver nanoparticle at $100 \mathrm{ppm}$ at one day after inoculation showing $15.3 \%$. The two fungicides showed lower disease reaction. The Amistar fungicide showed the lowest DLA\% (14.7) While, Fuji one fungicide showed $19.6 \%$. Results that the application of silver side cated nanoparticles at the concentration of $100 \mathrm{ug} \mathrm{ml}^{-1}$ showed DLA\% as $26.7 \%, 15.3$ and $20.0 \%$ as the most effective treatments at $3 \mathrm{~h}, 24 \mathrm{~h}$ and 5 days post-inoculation compared to $80.0 \%$ of the untreated control Table (2). 


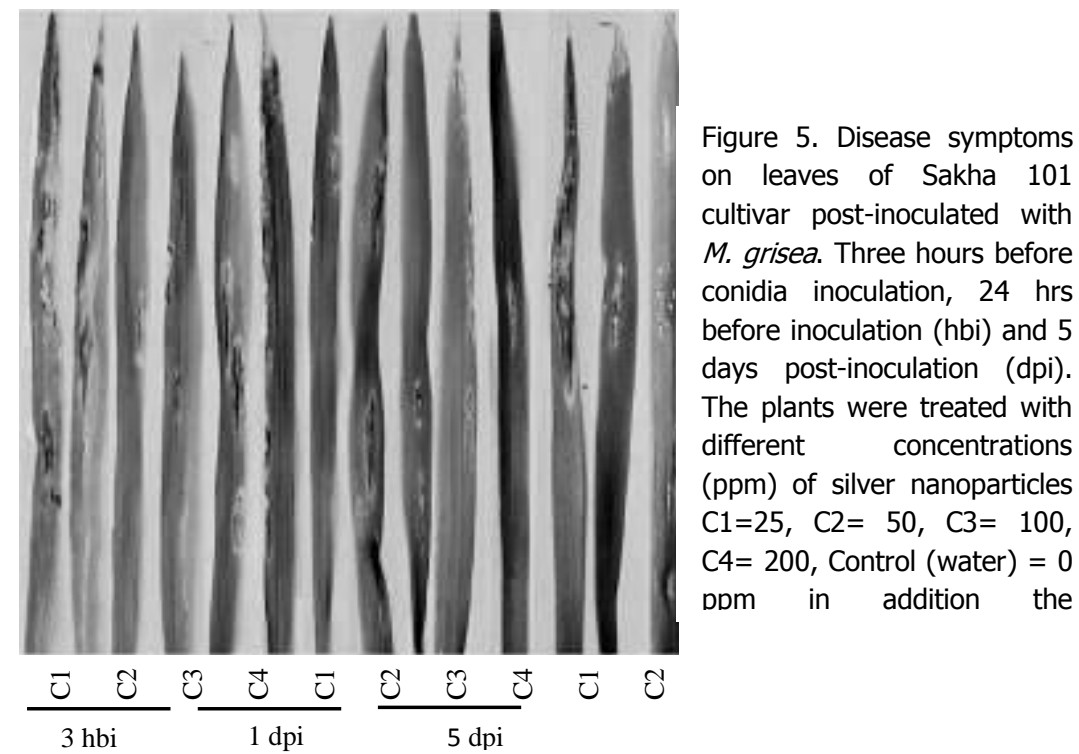

Table 2. Effect of silver nanoparticles on some blast disease parameters.

\begin{tabular}{|c|c|c|c|c|}
\hline Treatments & Concentration (ppm) & Severity & DLA \% & No. of spores $/ \mathrm{ml}$ \\
\hline Control (water) & 0 & $86.8^{\mathrm{a}}$ & $80.0^{\mathrm{a}}$ & $287.5^{\mathrm{a}}$ \\
\hline \multirow[t]{4}{*}{$3 \mathrm{hbi}$} & 25 & $39.7^{b}$ & $61.2^{\mathrm{C}}$ & $176.25^{\mathrm{ab}}$ \\
\hline & 50 & $48.9^{\mathrm{ab}}$ & $69.0^{\mathrm{b}}$ & $168.75^{\mathrm{ab}}$ \\
\hline & 100 & $46.7^{\mathrm{ab}}$ & $26.7^{9}$ & $150^{\mathrm{abcd}}$ \\
\hline & 200 & $40.7^{\mathrm{b}}$ & $32.8^{f}$ & $100^{\text {bcde }}$ \\
\hline \multirow[t]{4}{*}{$1 \mathrm{dpi}$} & 25 & $42.6^{\mathrm{b}}$ & $51.3^{d}$ & $25^{\mathrm{de}}$ \\
\hline & 50 & $42.4^{\mathrm{b}}$ & $62.0^{c}$ & $25^{\mathrm{de}}$ \\
\hline & 100 & $30.3^{b}$ & $15.3^{\mathrm{i}}$ & $31.25^{\text {cde }}$ \\
\hline & 200 & $41.2^{\mathrm{b}}$ & $48.0^{d}$ & $225^{\mathrm{ab}}$ \\
\hline \multirow[t]{4}{*}{$5 \mathrm{dpi}$} & 25 & $45.6^{\mathrm{b}}$ & $40.3^{\mathrm{e}}$ & $56.25^{\text {cde }}$ \\
\hline & 50 & $53.8^{\mathrm{ab}}$ & $43.7^{e}$ & $195^{\mathrm{ab}}$ \\
\hline & 100 & $35.9^{b}$ & $20.0^{\mathrm{h}}$ & $100^{\text {cde }}$ \\
\hline & 200 & $49.3^{\mathrm{ab}}$ & $43.7^{\mathrm{e}}$ & $56.25^{\text {cde }}$ \\
\hline Fuji-one & 100 & $27.5^{\mathrm{b}}$ & $19.6^{\mathrm{h}}$ & $6.25^{\mathrm{e}}$ \\
\hline Amstar & 100 & $22.9^{b}$ & $14.7^{i}$ & $6.25^{\mathrm{e}}$ \\
\hline LSD $5 \%$ & & 27.3 & 2.5 & 13.095 \\
\hline LSD $1 \%$ & & 36.8 & 3.4 & \\
\hline
\end{tabular}

Effect of silver nanoparticles on hyphal growth. As mentioned before, silver nanoparticles inhibited the hyphal growth and spores germination. Microscopic observation revealed that silver nanoparticles clearly damaged hyphae (Figure 6B), while hyphae treated with water appeared to remain intact (Figure $6 \mathrm{~A}$ ). In the treatment of silver nanoparticles, the shape of hyphal walls turned abnormal, many hyphae were collapsed at 24 hours after treatment. It could be concluded that the 
promising antifungal activity of silver nanoparticles against colony formation and hyphal growth of M. grisea was justified. The data clearly demonstrated that the silver nanoparticles strongly inhibited the fungal growth and colony formation unit in vitro. The microscopic data revealed that silver nanoparticle-treated hyphae were seriously damaged, resulting in the plasmolysis of hyphae.
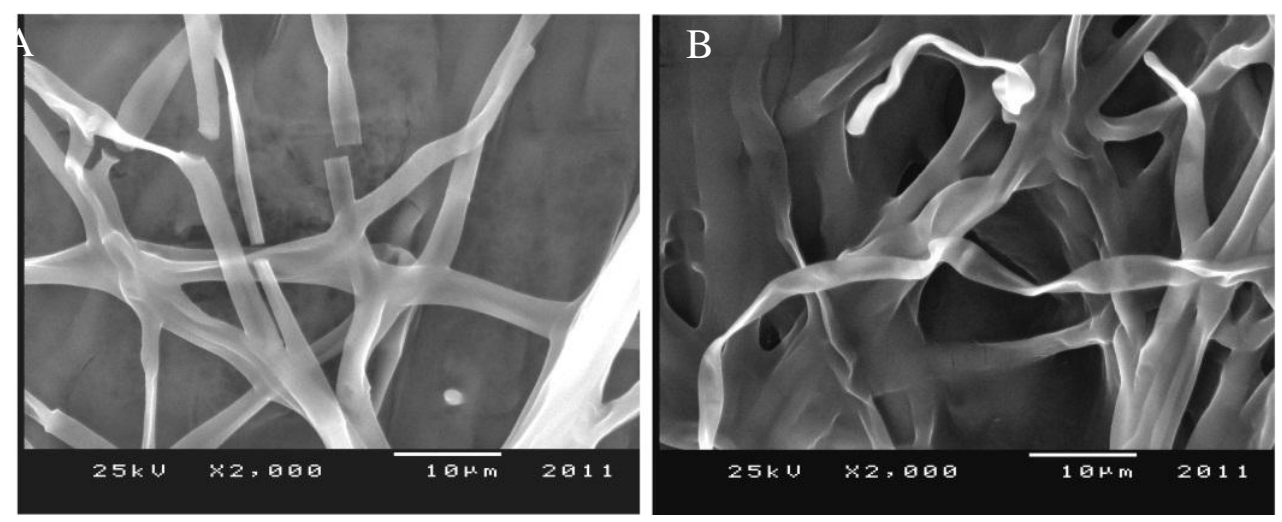

Figure 6. Electron micrographs of M. grisea hyphae treated with silver nanoparticles. Fungal hyphae grown on BDA plates were sprayed with either water as a control $(A)$ or equal volume of $100 \mathrm{ppm}$ silver nanoparticle solution (B). Photos were taken 24 hours after treatment.

It could be concluded that the promising antifungal activity of silver nanoparticles against colony formation and hyphal growth of M. grisea was clearly shown. The data clearly demonstrated that the silver nanoparticles strongly inhibited the fungal growth and colony formation unit in vitro. The microscopic data revealed that silver nanoparticle treated hyphae were seriously damaged hyphal walls, resulting in the plasmolysis of hyphae.

\section{DISCUSSION}

The antifungal activity of silver nanoparticles against $M$. grisea in both in vitro assays and in rice plants inoculation experiments was evaluated. Results obtained in this study confirm that silver nanoparticles have significant inhibitory effects on the fungal growth and colony formation of $M$. grisea. Previous studies suggested that nanometer-sized silvers possess different properties, which might come from morphological, structural and physiological changes (Nel et al., 2003). Silver nanoparticles are highly reactive as they generate $\mathrm{Ag}+$ ions while metallic silver is relatively unreactive (Morones et al., 2005). It was also shown that the nanoparticles efficiently penetrate into microbial cells, which implies lower concentrations of nanosized silvers would be sufficient for microbial control (Samuel and Guggenbichler, 2004). A previous study observed that silver nanoparticles disrupt transport systems including ion efflux (Morones et al., 2005). The dysfunction of ion efflux can cause 
rapid accumulation of silver ions, interrupting cellular processes at their lower concentrations such as metabolism and respiration by reacting with molecules. Also, silver ions are known to produce reactive oxygen species (ROS) via their reaction with oxygen, which are detrimental to cells, causing damage to proteins, lipids, and nucleic acids (Storz and Imlay, 1999; Hwang et al., 2008).

The present study results of microscopic data revealed that silver nanoparticle treated hyphae severely damaged hyphal walls, resulting in the plasmolysis of hyphae. Considering many cellular effects of silver ions, silver nanoparticle-mediated collapse in M. grisea hyphae is probably not only by damaging hyphal walls, but also other cellular effects, which need to be characterized.

The preventative and post-inoculation application of the silver nanoparticles effectively reduced disease severity on plants at all concentrations. A mechanism of this antifungal activity is suggested by the direct effect on germination and infection process in the fungi. M. grisea can cause foliar disease and reproduce as asexual conidia. Disease infection is initiated by the attachment of spores to the plant surface and formation of germ tubes (Tucker and Talbot 2001). Under favorable conditions of high humidity ( $\sim 100 \%$ relative humidity) and warm temperature $\left(25^{\circ} \mathrm{C}\right)$, conidia germinate, and the resulting germ tubes penetrate plant surfaces within 24 hrs (Howard and Ferrari 1989). Antifungal efficiency of silver nanoparticles was observed at $24 \mathrm{~h}$ after inoculation, suggesting that direct contact of silver with spores or germ tubes is critical in inhibiting disease development (Young et al., 2009). Moreover, antifungal efficiency of silver was also observed at 5 days after inoculation, suggesting that silver nanoparticles could have penetrated the plant cell wall and inhibited the disease development.

It could be concluded that, silver nanoparticles can be used effectively in the control of rice blast disease and the prevention of deleterious infections, even though there are no phytotoxicity appeared on rice. Silver may be less toxic to humans and animals than synthetic fungicides. Our results support the hypothesis that silver nanoparticles are suitable for formulating new types of fungicidal materials. Our follow-up research focuses on extended applicability of silver for control of $M$. grisea in the field, and evaluation of the efficacy of silver on different types of pathogens causing a problem for rice production. Further research should focus on the development of silver compounds and mixing with fungicides. At the same time, the environmental tracking of silver when applied in the field is important to assess the impact on environmental and human health. This information is imperative for future registration and labeling of the silver nanoparticles as fungicides for crop protection. However, further investigation on the effect of copper, widely used in control of plant diseases in the form of nanoparticles must be tried. 


\section{Acknowledgment}

The author would like to thank Prof. Awatif Hendi Physics Department, College of Science, King Saud University, Saudi Arabia for providing silver nanoparticle used in this study.

\section{REFERENCES}

1. Atkins, J.G., A. L. Robert, C. R. Adair, K. Goto, T. Kozako, R. Yanagida, Y. Yamada and S. Matsumoto. 1967. An international set of rice varieties for differentiating races of Pyricularia oryzae. Phytopathology, 57: 298-301.

2. Bae C.H., S.M. Nam, S.M. Park. 2002. Formation of silver nanoparticles by laser ablation of a silver target in $\mathrm{NaCl}$ solution. Applied Surface Science, 197: 628 634.

3. Bragg, P. D. and D. J. Rannie. 1974. The effect of silver ions on the respiratory chain of Escherichia coli. Can J Microbiol; 20:883-9.

4. Coca, M. Peñas, G. Gómez, J. Campo, S. Bortolotti, C. Messeguer, J. San Segundo B. 2006. Enhanced resistance to the rice blast fungus Magnaporthe grisea conferred by expression of a cecropin A gene in transgenic rice, Planta 223,392406.

5. Duncan, D.B. 1955. Multiple ranges and multiple $F$ test. Biometrics, 11:1-42.

6. Gomez, K.A. and A.A. Gomez. 1984. Statistical procedures for Agricultural Research. Second Edition. John Wiley \& Sons, New York.

7. Elchiguerra, J. L., J. L. Burt, J. R. Morones, A. Camacho-Bragado, X. Gao, H. H. Lara, and M. J. Yacaman. 2005. Interaction of silver nanoparticles with hiv-1. J. Nanobiotechnol. 3:6.

8. Howard, R. and M. Ferrari. 1989. Role of melanin in appressorium function. Exp. Mycol. 13:403-418.

9. Hwang, E.T., J.H. Lee, Y. J. Chae, Y.S. Kim, B.C. Kim, B.I. Sang, MB. Gu. Analysis of the toxic mode of action of silver nanoparticles using stress- pecific bioluminescent bacteria. Small 2008;4:746-50.

10. IRRI (International Rice Research Institute) 1996. Standard Evaluation System for Rice (IRRI) P.O. Box 933. 1099 Manila Philippines.

11. Khanna, P.K., N. Singh, D. Kulkarni, S. Deshmukh, S. Charan, P.V. Adhyapak. 2007. Water based simple synthesis of redispersable silver nano-particles. Materials Letters, 61: 3366 - 3370

12. Lamsal, K., S. W. Kim, J. H. Jin Hee Jung, Y. S. Kim, K.S. Kim and Y. S. Lee. 2011. Inhibition effects of silver nanoparticles against powdery mildews on Cucumber and Pumpkin. Mycobiology 39(1) : 26-32. 
13. Morones, J. R., Elechiguerra, J. L., Camacho, A., Holt, K., Kouri,J. B., Ramirez, J. T. and Acaman, M. J. 2005. The bactericidal effect of silver nanoparticles. Nanobiotechnology 16:2346- 2353.

14. Min, J. S., Kim, K. S., Kim, S. W., Jin Hee Jung, J. H., Lamsal, K. and Kim, S. B. 2009. Effects of colloidal silver nanoparticles on Sclerotium-forming phytopathogenic fungi. Plant Pathol. J. 25(4): 376-380.

15. Nel, A., Xia, T., L. Mdler and N. Li. 2003. Toxic potential of materials at the nanolevel. Science 311:622-627.

16. Ou, S.H. 1985. Rice Diseases II edition. CMI, Kew, England. pp. 337-364.

17. Richards, R.M. 1981. Antimicrobial action of silver nitrate. Microbios; 31:83-91.

18. RRTC (Rice Research and Training Center) 2010. Annual rice national campaign report of rice program. Field Crops Research, Agric. Research Center, Ministry of Agriculture, Egypt.

19. Samuel, U. and J. P. Guggenbichler. 2004. Prevention of catheter related infections: the potential of a new nano-silver impregnated catheter. Intl. J. Antimicrobial Agents 23S1: S75-S78.

20. Sehly, M.R., Z.H. Osman and E.A. Salem. 2002. Rice diseases. In: Rice in Egypt, pp 301.

21. Subhankar Roy-Barman and Bharat B. Chattoo. 2005. Rice blast fungus sequenced. Current science, (89) 6. 930-931.

22. Storz, G., Imlay, J.A. 1999. Oxidative stress. Curr Opin Microbiol; 2:188-94.

23. Thurman, R.B., C.P. Gerba, G. Bitton. 1989. The molecular mechanisms of copper and silver ion disinfection of bacteria and viruses. Crit. Rev Environ Sci. technol. 18:295-315.

24. Tucker, S. L., and N. J. Talbot. 2001. Surface attachment and pre-penetration stage development by plant pathogenic fungi. Annu. Rev. Phytopathol. 39:385417.

25. Young, K. J., Byung H. Kim and Geunhwa Jung 2009. Antifungal activity of silver ions and nanoparticles on Phytopathogenic Fungi. Plant Disease, 1037-1043.

26. Yeo, S. Y., H. J. Lee and S. H. Jeong. 2003. Preparation of nanocomposite fibers for permanent antibacterial effect. J. Mater. Sci. 38:2143-2147.

27. Zeigler, R.S., S.A. Leong , P.S. Teng, editors. 1994. Rice blast disease. In: Zeigler RS, Leong SA, Teng PS, editors. Rice blast disease. Wallingford, Oxon (United Kingdom): CAB International, Los Baños (Philippines):IRRI. 626 p. 


\section{التاثير المثبط لجزيئات الفضه النانونيه علي}

\section{Magnaporthe grisea مرض اللفحه في الارز}

\section{رباب مددوح أحمد العماوي و ربيع عبد الفتاح سعد الثافعي2}

$$
\begin{aligned}
& \text { 1 قسم بحوث أمراض الأرز - معهُ بحوث أمراض النباتات - مركز البحوث الزرراعية - مصر }
\end{aligned}
$$

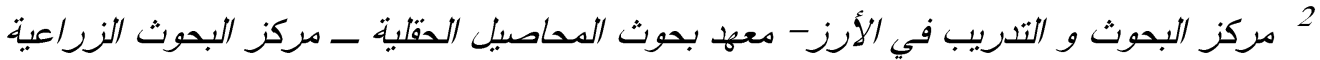

يعتبر مرض لفحة الأرز ، والمتسبب عن الفطر Magnaporthe grisea من أخطر العوامل الحيوية التي تؤثر علي إنتاجيه محصول الأرز Oryza sativa علي مستوي العالم. وهو من أهم الفطريات المحدة لزر اعة محصول الأرز في مصر • و كيبب خساره كبيرة في المحصول و خاصة

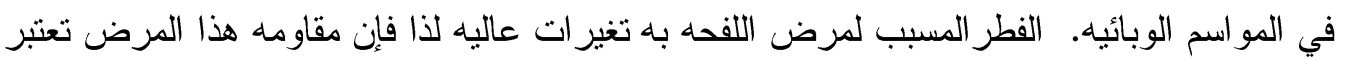

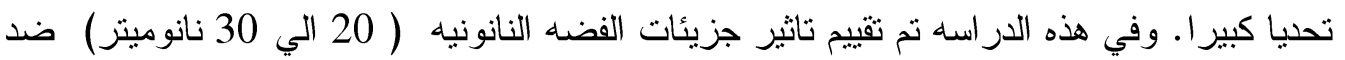
فطر لفحه الأور اق في الأرز تحت ظروف النمو المختلفه في المعل و الصوبة . و كانت المعاملات تحت ظروف المعدل، أوضحت معامله مزارع فطر اللفحه باربع نركيزات 25، 50، 50، 100، و و 200 جزء في المليون من جزيئات الفضه النانونيه تاثير ا مثبطا علي كلا من نمو الهيفات الفطريه و عدد بهد

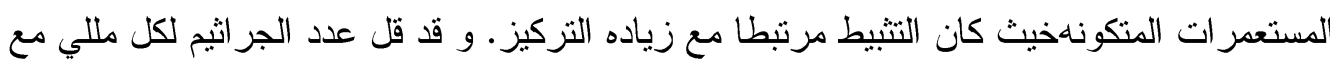
كل المعاملات. أيضا تحت ظروف الصوبة، رشت أوراق بادرات الأرز عند عمر 21 يوم بجزيئات

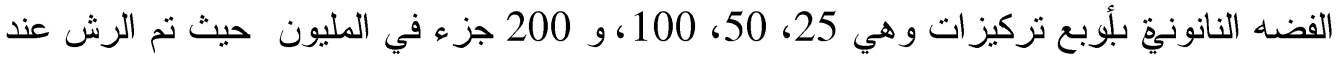
ثلاث مو اعبد من العدوي الصناعية وهي ثلاث ساعات قبل العدوي، يوم بعد العدوي و خمسه لـ أيام

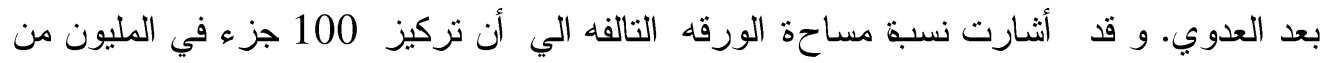

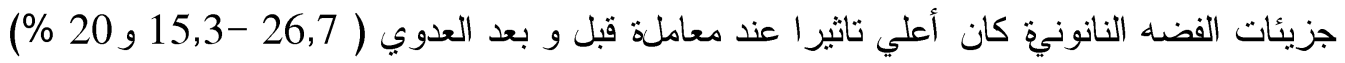
بالتو الي مقارنه بالكنترول غير المعامل حيث سجل 80 \% . كما أوضحت المعاملة بالمبيدات الفطريه فوجي ون (ايزوبروثيولان) و الأميستار (ازوستروبين) عند تركيز 100 جزء في المليون لكل بهل

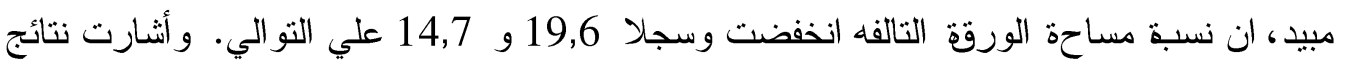
الميكروسكوب الأكتروني الماسح إلي أن جزيئات الفضة النانونية سببت تاثير ات و اضحه علي نمو الهيفات الفطريه تحت المعاملة. 